\title{
Micro-Raman analysis of pigments from hunter-gatherer archaeological sites of North Patagonia (Argentina)
}

\author{
Anastasia Rousaki, ${ }^{a}$ Cristina Bellelli, ${ }^{\text {b }}$ Mariana Carballido Calatayud, ${ }^{\text {b }}$ \\ Veronica Aldazabal, ${ }^{c}$ Graciella Custo, ${ }^{d}$ Luc Moens, ${ }^{a}$ Peter Vandenabeele ${ }^{e_{*}}$ \\ and C. Vázquez ${ }^{\mathrm{d}, \mathrm{f}}$
}

\begin{abstract}
In Northwestern Patagonia, many archaeological sites can be found that testify human occupation by hunter-gatherer groups during the Holocene period. The general purpose of archaeological research in this area is to obtain information on the movements of these groups between the dry steppe and the different sectors in the forests. This paper reports on the results of the first spectroscopic analysis of samples from the archaeological excavation of two hunter-gatherer regions in Northern Patagonia (Traful Lake and Manso River areas). Thirty samples of rock art fragments, grinding tools, shell, raw pigment material, as well as painted ceramics and beads were examined with micro-Raman spectroscopy, complemented with X-ray fluorescence (XRF) analysis. Micro-Raman analysis revealed mostly the use of haematite $\left(\mathrm{Fe}_{2} \mathrm{O}_{3}\right)$ as the red chromophore. The presence of associated minerals and silicates indicated that clay-like material (ochre) was used, instead of pure haematite. Although not fully conclusive, Raman spectroscopic results tend to indicate that in some samples haematite might be formed by heating iron-containing ochres. Copyright $\odot 2015$ John Wiley \& Sons, Ltd.
\end{abstract}

Keywords: micro-raman spectroscopy; hunter-gatherers; north Patagonia; pigment identification; haematite; archaeometry

\section{Introduction}

In general, archaeological research in Northwestern Patagonia aims to generate knowledge on the use of forest and ecotonal environments by hunter-gatherer groups during the Holocene. This research investigates the characteristics of the human groups and their circulation between the steppe and the Andean-Patagonian forest and between different sectors in the forest. Within this broad research field, the current work focusses on a particular aspect of the material culture of the hunter-gatherer groups in Northwestern Patagonia, namely on their pigments and paint.

Pigments were important resources used for rock art, body painting and objects decoration. Often they were of mineral origin, although in some cases, they could also be synthesized (intentionally as a by-product of an existing mineral). For example, if goethite is fired under appropriate conditions, haematite is formed.

Although rock art plays an important role in Patagonian archaeology, little information is available on chemical or spectroscopic analysis of the painting materials. Inorganic pigments applied on different supports were in general identified by mineralogical means (i.e. visual inspection and microscopy). In the 1970s some studies were carried out by using X-ray diffraction (XRD), and later other techniques were included, such as elemental analysis through scanning electron microscopy with energy dispersive $\mathrm{X}$-ray analysis (SEM-EDX) or X-ray fluorescence (XRF), and molecular analysis with Fourier-transform infrared spectroscopy (FT-IR). Boschin et al. (2011) ${ }^{[1]}$ presented an excellent historical review of the work using these techniques. In 2007 Maier et al. ${ }^{[2]}$ reported on the analysis of two archaeological samples of colour paste (crayons) from Cave Loncoman (Rio Negro, Argentina). These were examined by FT-IR and FT-Raman spectroscopy, as well as by gas chromatography (GC) and gas chromatography-mass spectrometry (GC-MS). Although this paper mainly focusses on the identification of the organic fraction in the samples, a noisy spectrum showing the Raman bands of haematite was published. Darchuk et al. ${ }^{[3]}$ reported on the analysis of pigment samples from the Carriqueo rock shelter (Rio Negro province, Argentina) by SEM-EDX, FTIR and Raman spectroscopy. The same samples were also analysed by synchrotron radiation $\mathrm{XRD}$. $^{[4]}$

In this paper, Raman spectroscopy was selected as first technique of choice for the analysis of the archaeological paint fragments. The results are complemented by XRF analysis. Its non-destructive

\footnotetext{
* Correspondence to: Peter Vandenabeele, Department of Archaeology, Ghent University, Sint-Pietersnieuwstraat 35, B-9000 Ghent, Belgium. E-mail: vazquezcristi@gmail.com

a Department of Analytical Chemistry, Ghent University, Krijgslaan 281(S-12), Ghent B-9000, Belgium

b -INAPL-UBA, CONICET, 3 de Febrero 1370. (1426), Buenos Aires, Argentina

c Instituto Multidisciplinario de Historia y Ciencias Humanas, CONICET, Saavedra 15, 5․ (1083), Buenos Aires, Argentina

d Gerencia Química, Comisión Nacional de Energía Atómica, Av. Gral Paz 1499. (1650) San Martín, Buenos Aires, Argentina

e Department of Archaeology, Ghent University, Sint-Pietersnieuwstraat 35, Ghent B-9000, Belgium

f Facultad de Ingeniería, Universidad de Buenos Aires, Av. P. Colón 850 (1063), Buenos Aires, Argentina
} 
character and the ability to record a spectrum of (pigment) particles down to one micrometre, are advantageous features, that make micro-Raman spectroscopy excellently suited for this type of research. The suitability of the technique for research was proven in several other cases, investigating rock art in France, ${ }^{[5]}$ Ethiopia, ${ }^{[6,7]}$ Eritrea, ${ }^{[8]}$ Italy ${ }^{[9]}$ and Spain. ${ }^{[10-12]}$ Edwards et al. ${ }^{[13]}$ focus on the degradation products and the formation of oxalates because of microbial attack by bacteria, algae, fungi, or lychens. Recently, mobile Raman instrumentation was used for the direct analysis of rock art in Spain, ${ }^{[14]}$ France, ${ }^{[15]}$ and South-Africa. ${ }^{[16-19]}$

In this paper, we report for the first time results of micro-Raman analysis of samples from the two archaeological regions in Northern Patagonia, namely Traful Lake area and Manso River area, which are ca. $110 \mathrm{~km}$ away from each other (Fig. 1). The focus of this work is on the analysis of red paint. Not only rock art fragments are examined, but also pigmented beads and painted ceramics. Moreover, spectra were recorded of raw materials that were found on the archaeological site, of shell fragments and of grinding tools. The molecular and crystalline information that was obtained from the micro-Raman analyses was completed with elemental data from wavelength dispersive X-ray fluorescence (WDXRF). This work identifies the chromophores in these samples, as well as their associated minerals. Therefore, information can be obtained on the source of the raw minerals and a greater understanding on the processing of these raw materials.

\section{Environmental, geological, and archaeological context of the areas in the Andean-Patagonian forest}

The samples presented in this work were recovered from two archaeological areas located in the Andean Patagonian forest, between $40^{\circ} 37^{\prime} \mathrm{S}$ and $41^{\circ} 36^{\prime} \mathrm{S}$ and within the $71^{\circ} \mathrm{W}$ : the Traful lake, at the Nahuel Huapi National Park (Neuquén province), and the lower Manso river valley (Rio Negro province) (Fig. 1). The continental

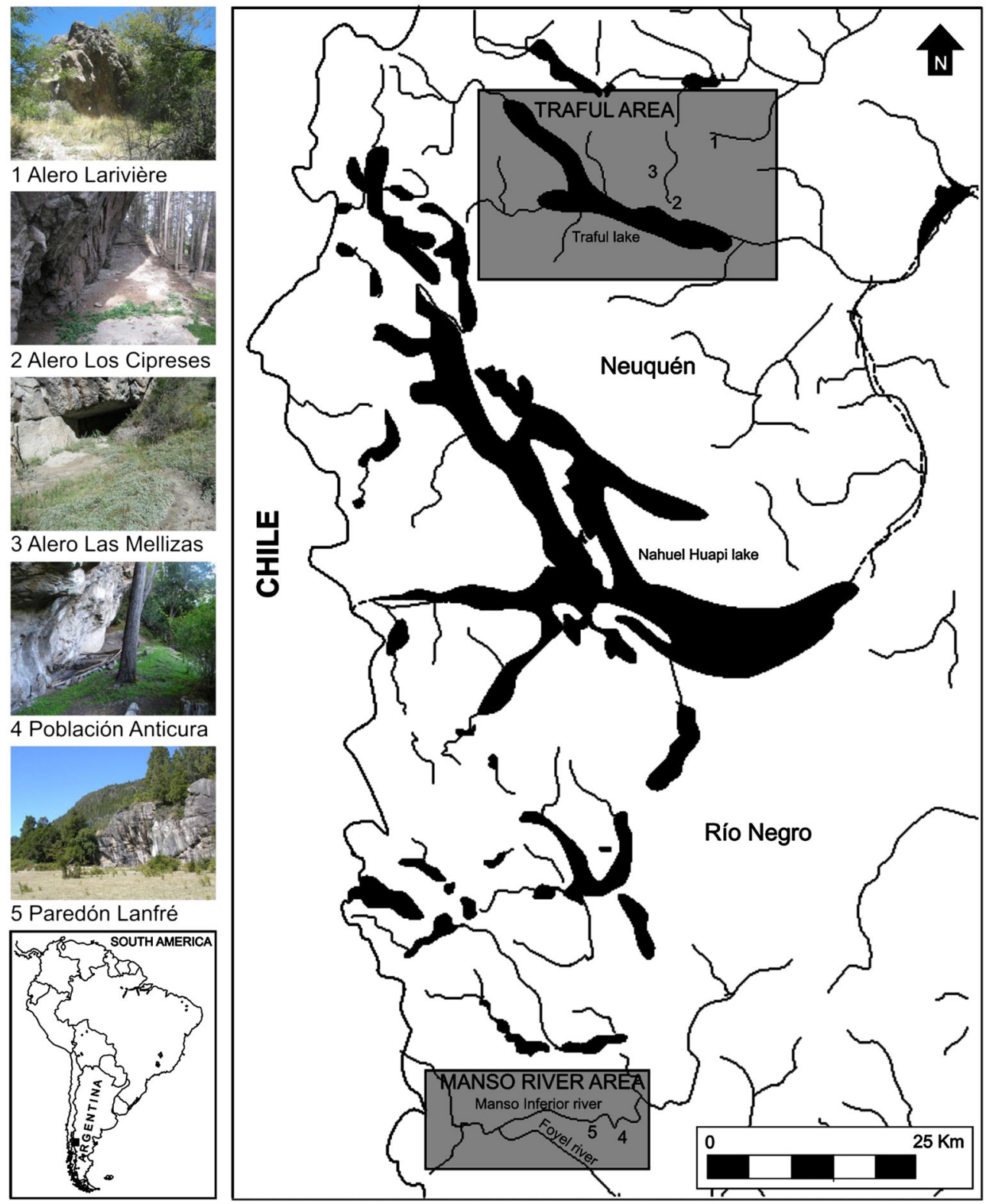

Figure 1. Map, indicating the location of the different archaeological sites in Northern Patagonia that were studied in this paper. 
forest in Patagonia extends along the Andes between $39^{\circ} \mathrm{S}$ and $53^{\circ} \mathrm{S}$. It is disposed as a band of approximately $2000 \mathrm{~km}$ long and $120 \mathrm{~km}$ wide, presenting a great diversity concerning forest and soils. $^{[20]}$ Typical vegetation are tree species such as coihue (Nothofagus dombeyi), ñire (Nothofagus antarctica), and cypress (Austrocedrus sp.) in rocky outcrops, replaced by lenga (Nothofagus pumilio) at $900-\mathrm{m}$ altitude. There is also a dense understory layer with a diversity of ferns, lichens, epiphytes, mosses, climbing plants, and lianas. ${ }^{[21]}$

The two studied sectors are glacial valleys, located in the Septentrional Patagonian Cordillera, characterized by an abrupt relief because of the Andean orogeny, with riffs that have a relative height of more than $1500 \mathrm{~m}$ from the floor of the valley, usually with south trending orientation. ${ }^{[22]}$ Quaternary glaciations were the main geomorphological processes, and the whole study area presents characteristics of glacier modelling: troughs and circuses, erosive forms, like roches moutonnées, and whaleback forms in which most of the rock art sites are located. Depositional landforms as numerous frontal and lateral moraines mark the different positions of the ice. After the Last Maximum Glacial, which occurred in the region between 18 and 14 thousand years ago, many readvancements have been detected. The Tardiglacial presents moraines with ages ranging between 12 and 10 thousand years, and the Neoglacial (between 4500 and 300 years BP), with several advancements (at least three, including the last one), is equivalent to the Small Ice Age. Lithologies of different ages and origins are present: volcanic and volcanoclastic rocks, andesite, andesitic tuffs, ignimbrites, schists, gneisses, quartzites, amphibolites, and migmatites, where small particles of tonalitic and granodioritic compositions are inserted. ${ }^{[23,24]}$ The substrates of the rock art in the Manso area are granitoid and pyroclastic rocks, ${ }^{[22]}$ whereas in the Traful area volcanic rocks (e.g. tuffs) were present. ${ }^{[25]}$ These shelter sites show a considerable degree of natural deterioration because of four main factors:

1. a high susceptibility to physical weathering of rocks that serve as support,

2. bioclimatic conditions that favour the weathering of rocks (humid climates and tree vegetation which acidified the soils),

3. presence of Andic soils and

4. high activity of mass removal processes (essentially rockfalls) because of the geomorphology of the region. ${ }^{[22]}$

According to human occupation chronologies at the sites under study in both areas, we infer that the hunter-gatherer societies interacted with the mild climate variations of the Holocene, which did not produce significant environmental changes so as to raise natural barriers between them, their displacement, and the resource availability.

In this environment, archaeological sites with rock art are typically in rock shelters, located on the riverside or near the lakes. The paintings are mostly abstract pictograms, forming simple or complex geometrical figures, and are rarely figurative (human or animals shapes, their footprints or tracks). Red colour tones are predominant and to a lesser extent, yellow, green, white, and black. This kind of pictograms is characteristic of the Grecas style, which in northern Patagonia began 1100 BP. In recent times (about 300 years BP) figurative motifs (horses and riders with Spanish cloths) evidence the contact with Europeans. ${ }^{[26,27]}$ In the area of Traful lake, the archaeological sites are situated on the North shore of the lake and in the middle and upper valley of the homonymous river, in a transitional forest between the Austrocedrus sp. and Nothofagus sp., near the rainforest and the steppe. The occupations were reported since 3500 to 500 years BP corresponding to huntergatherers who took advantage of resources from a large area around. ${ }^{[28]}$ The archaeological settlements are located in rock shelters with a predominantly geometrical art on the walls except for some figurative motifs in Alero Las Mellizas, into an archaeological context dated about 600 BP. The characteristic archaeological contexts consist on a lithic flake industry, some grinding tools, bivalves remains of river food resources reused as artifacts, and bones from forest and steppe fauna as huemul (Hippocamelus bisulcus, a South Andean deer) and guanaco (Lama guanicoe). Pottery is rarely present since 1500 years BP; however, it appears more extensively since $850 \mathrm{BP}^{[29,30]}$ Opposite to this, raw pigment materials were registered all over the archaeological sequence. ${ }^{[31]}$ In the lower Manso river area, 22 sites with rock art were located on the hillsides bordering the valleys in a close temperate forest. Human occupation occurs from 8000 years BP to historic times ( 300 years BP). The earliest archaeological record is sparse and limited to the lower levels of the site Población Anticura. At the time, we found bone artefacts, grinding tools with and without adhered pigments, lithic artefacts, prepared pigments, archaeofaunal remains, and shell fragments. Since 1600 years BP, a larger use of the space on the 22 surveyed sites is checked up. Near 1300 BP the first recorded rock art appears and the ceramic technology is incorporated. Besides, archaeological evidence consists of lithic artefacts, grinding tools with and without pigment, ceramic fragments, human bones, archaeofaunal remains, shell fragments, beads, and a notable increase of raw pigment material. ${ }^{[32,33]}$

In short, both areas were occupied by pedestrian huntergatherer societies, beginning about 8000 years ago in the Manso sites and 4000 years ago in the Traful sector, and persisting until the dissolution of indigenous societies in the nineteenth century. They also took advantage of freshwater molluscs and some local vegetables. The technology was focused on the manufacturing and use of stone tools, decorated flat stones and axes made in local rocks, ceramic manufacturing, beads from shells of molluscs, mineral pigments possibly used for painting and bone instruments (some decorated), etc. Many of these sites have rock art in small rock shelters or block walls, which are sometimes unprotected. The kind of pictograms corresponds to the regional Grecas style, characterized by a prevalence of geometric-abstract motifs with few figurative designs, painted in different shades of red, yellow, white, and green.

\section{Experimental}

\section{Techniques}

Micro-Raman spectra were recorded with a Bruker Senterra spectrometer, by using a diode laser $(785 \mathrm{~mm})$ and a green Nd:YAG $(532 \mathrm{~nm})$ laser, where the power could be reduced $(100 \%, 50 \%$, $25 \%, 10 \%$, and $1 \%$ ) by entering filters in the beampath. Spectra were obtained in the range of $60-2750 \mathrm{~cm}^{-1}$ and $80-2660 \mathrm{~cm}^{-1}$ for the $532-\mathrm{nm}$ and the $785-\mathrm{nm}$ lasers, respectively. The system is equipped with a thermoelectrically cooled CCD detector, operating at $-65^{\circ} \mathrm{C}$. The spectrometer used $5 \times, 20 \times, 50 \times$, or $100 \times$ objective lenses to focus the laser beam on the sample and to collect the backscattered Raman signal. Corresponding spot sizes are ca. 50, 10,4 , and $2 \mu \mathrm{m}$, respectively. Laser power, total measuring time, and number of accumulations were set to obtain a good quality Raman spectra (good signal-to-noise ratios). The instrument is controlled by OPUS ${ }^{\circledR}$ software, while data processing was performed by using Thermo Grams/Al $8.0^{\circledR}$ suite software (Thermo Galactic). 
To cover possible sample inhomogeneity, for each sample at least three different spectra were recorded. The obtained spectra were baseline corrected and compared with pure compounds and with spectra from published literature.

In order to achieve complementary information on the elemental composition, samples were also investigated by using a Venus Minilab Panalytical wavelength dispersive X-ray fluorescence spectrometer, equipped with a Scandium X-ray tube. The tube voltage was fixed at $50 \mathrm{kV}$ and $20-\mathrm{mA}$ tube current. The instrument is equipped with two detectors: a flow gas detector $\left(\mathrm{Ar}-\mathrm{CH}_{4}\right)$, for the light elements ( $\mathrm{Na}$ to $\mathrm{Ca}$ ) and a scintillation detector for heavier elements ( $\mathrm{Ti}$ to $\mathrm{U}$ ). All measurements were performed in vacuum. Scanning for the elements from Ti to $U$ lasted $30 \mathrm{~min}$ in total, while for each of the lighter elements $1 \mathrm{~min}$ of measuring time was required. The spectra were recorded using Panalytical Venus software, data processing was performed using Venus Qualitative Analysis (Panalytical). During the processing of the spectra, it is necessary to select the elements for the semi-quantitative analysis. Because of matrix-effects and size of the samples, the quantification of the detected elements is not so precise, but trends can be observed. In general, light elements were not incorporated in the semi-quantitative analysis, as they give rise to serious uncertainties. As a rule of thumb, it is estimated that the detection limits of light elements are ca. 2 to 3 orders of magnitude higher than those of heavy metals.

\section{Samples}

Samples were analysed from archaeological sites from two different regions in Northern Patagonia: Traful Lake and Manso River. An overview of the samples is given in Table 1. Rock art samples were obtained from exfoliated areas. Materials under study from the Traful Lake area consist of ceramic fragments, fallen fragments of rock art, and raw pigment material found in three archaeological sites: Alero Larivière (ALR), Alero Los Cipreses (ALC), and Alero Las Mellizas (ALM). From the Manso river area, samples were retrieved from the archaeological sites Población Anticura (PA) and Paredón Lanfré (PL). The analysis was also performed on shell fragments and beads, both exhibiting red spots visible with the naked eye. Moreover, pigments recovered from grinding tools were also analysed.

The rock art fragments seemed to consist of a single layer, and no priming layer between the rock and the paint was observed. There was no uniform patina observed over the paint layer, but in some areas the paint layers seemed to flake off, which could eventually

Table 1. Overview of the samples in this study. Colour indication is based on the classification of soil colours by using the Munsell soil chart. In some cases, it was impossible to make the Munsell chart classification, as the samples were too small (marked with **). Artefacts are dated by using radiocarbon dating. Dates marked with an asterisk $\left(^{*}\right)$ are obtained from the relative chronology of the archaeological layer

\begin{tabular}{|c|c|c|c|c|c|}
\hline Area & Site & Sample & Sample type & Colour (Munsell soil chart) & Date \\
\hline \multirow[t]{13}{*}{ Traful lake area } & Alero Larivière & 1 & Raw pigment & 7.5R4/8-red & $780 \pm 50 \mathrm{BP}$ \\
\hline & Alero Larivière & 2 & Raw pigment & 2.5YR4/8—red & $780 \pm 50 \mathrm{BP}$ \\
\hline & Alero Larivière & 3 & Raw pigment & $2.5 Y$ 5/4-light olive brown & $780 \pm 50 \mathrm{BP}$ \\
\hline & Alero Las Mellizas & 4 & Raw pigment & $2.5 Y$ 5/4-light olive brown & $590 \pm 90 \mathrm{BP}$ \\
\hline & Alero Las Mellizas & 5 & Raw pigment & 10R4/8_-dark reddish & $590 \pm 90 \mathrm{BP}$ \\
\hline & Alero Las Mellizas & 6 & Raw pigment & 7.5R3/8—dark red & $590 \pm 90 \mathrm{BP}$ \\
\hline & Alero Las Mellizas & 7 & Raw pigment & 10R5/8-red & $590 \pm 90 \mathrm{BP}$ \\
\hline & Alero Las Mellizas & 8 & Raw pigment & 7.5R3/8_dark red & $590 \pm 90 \mathrm{BP}$ \\
\hline & Alero Larivière & 9 & Rock art & 2.5YR4/8-red & $780 \pm 50 \mathrm{BP}$ \\
\hline & Alero Larivière & 10 & Rock art & 2.5YR5/8—red & $780 \pm 50 \mathrm{BP}$ \\
\hline & Alero Los Cipreses & 11 & Pottery & 2.5YR5/8-red & $840 \pm 90 \mathrm{BP}$ \\
\hline & Alero Los Cipreses & 12 & Pottery & Black ** & $840 \pm 90 \mathrm{BP}$ \\
\hline & Alero Los Cipreses & 13 & Pottery & Black ** & $840 \pm 90 \mathrm{BP}$ \\
\hline \multirow[t]{20}{*}{ Manso River area } & Población Anticura & 14 & Raw pigment & Red ${ }^{* *}$ & $300 \pm 50 \mathrm{BP}$ \\
\hline & & & & & $480 \pm 70 \mathrm{BP}$ \\
\hline & Población Anticura & 15 & Raw pigment & 2.5YR5/4—reddish brown & $400 \pm 70 \mathrm{BP}$ \\
\hline & Población Anticura & 16 & Raw pigment & $5 \mathrm{R} 4 / 8$-red & $400 \pm 70 \mathrm{BP}$ \\
\hline & Población Anticura & 17 & Raw pigment & 2.5YR4/8-red & $700 \pm 60 \mathrm{BP}$ \\
\hline & Población Anticura & 18 & Raw pigment & 10YR8/3 — very pale brown & $700 \pm 60 \mathrm{BP}$ \\
\hline & Población Anticura & 19 & Raw pigment & 7.5YR4/6—strong brown & $810 \pm 50 \mathrm{BP}$ \\
\hline & Población Anticura & 20 & Raw pigment & 2.5YR4/6—red & $660 \pm 50 \mathrm{BP}$ \\
\hline & Población Anticura & 21 & Raw pigment & 10YR7/4-very pale brown & $810 \pm 50 \mathrm{BP}$ \\
\hline & Población Anticura & 22 & Raw pigment & $\operatorname{Red}^{* *}$ & $7820 \pm 110 \mathrm{BP}$ \\
\hline & & & & & $8080 \pm 130 \mathrm{BP}$ \\
\hline & Población Anticura & 23 & Grinding tool & $\operatorname{Red} * *$ & $4724 \pm 54 \mathrm{BP}$ \\
\hline & Paredón Lanfré & 24 & Grinding tool & 10R3/6—dark red & * 300-500 BP \\
\hline & Población Anticura & 25 & Grinding tool & 10R4/4—weak red & ${ }^{*} 0-300 \mathrm{BP}$ \\
\hline & Paredón Lanfré & 26 & Shell fragment & 5R6/8—light red & * 300-700 BP \\
\hline & Paredón Lanfré & 27 & Shell fragment & 2.5YR4/8-red & * 300-700 BP \\
\hline & Paredón Lanfré & 28 & Shell fragment & $5 \mathrm{R} 5 / 8$-red & * 300-700 BP \\
\hline & Población Anticura & 29 & Shell fragment & $5 \mathrm{R} 5 / 6$-red & $700 \pm 60 \mathrm{BP}$ \\
\hline & Población Anticura & 30 & Bead & 7.5R6/6—light red & $300 \pm 50 \mathrm{BP}$ \\
\hline & & & & & $480 \pm 70 \mathrm{BP}$ \\
\hline
\end{tabular}


be caused by deterioration of the substrate. In specific areas microbial activity (lichens) was observed. At some areas efflorescence of salts is observed, because of the leaking of water through cracks in the rock.

\section{Results and discussion}

During this study, 30 samples were investigated from two archaeological regions in Northern Patagonia. Most of these samples revealed clearly the Raman spectrum of haematite $\left(\mathrm{Fe}_{2} \mathrm{O}_{3}\right)$, but often other phases could be identified. Haematite is a typical red chromophore that is usually encountered in many Earth pigments, often commonly named as 'ochres'. Next to haematite, ochres always contain silicates. The shade of the ochre is not only determined by the haematite, but other chromophores might be present as well, such as manganese oxides (black), carbon (black), titanium dioxides (white), or iron-containing minerals, such as goethite $(\alpha-\mathrm{FeOOH})$, limonite $(\beta-\mathrm{FeOOH})$, lepidocrocite $(\gamma-\mathrm{FeOOH})$, etc. Moreover, crystal size may also be of influence on the observed colour.

In general, ochres can be distinguished in two large groups, depending whether the main colouring material is an anhydrous ferric oxide or a hydrous ferric oxide. The first group contains materials that are known under various pigment names, such as caput mortuum, burnt Sienna, Cassel earth, etc. Haematite is combined with clays and/or manganese oxides that influence the hue of the pigment. The painting materials of the second group are given the generic term 'yellow ochre' and may contain different mineral phases, such as limonite, goethite, lepidocrocite. ${ }^{[34]}$ Using the chromatic properties of ochres to identify them or to differentiate them from pure haematite is not straightforward. Colour and hue are not only determined by the mineral mixture, but particle size is also of influence. The distinction between pure mineral haematite and haematite in clay matrices (ochres) has been addressed in many studies. Moreover, haematite can also be formed from the thermal treatment of goethite at moderate temperatures $\left(280-350^{\circ} \mathrm{C}\right)$ under oxidizing conditions. ${ }^{[9,13]}$

In this study, Raman microscopy was used as the main technique to identify the minerals in the red pigment, and we try to provide information on the production process of the pigment. Although Raman spectroscopy is very effective in discriminating between the ordered and disordered structure in haematite ${ }^{[7,35]}$, this property cannot be used to distinguish between natural haematite and haematite that was produced through heating goethite. The degree of crystallinity is not only affected by the origin (mineral or not) of the haematite but it is also influenced by grinding, weathering, and biodegradation. It is also described ${ }^{[7,8,18,36]}$ that in clay-rich ochres doping with aluminium can cause band broadening and shifts to the lower wavenumbers of the haematite bands. Moreover, the haematite Raman spectrum is highly dependent on the energy of laser used as well as on the orientation of the microcrystals. ${ }^{[18]}$ That might be an explanation of why in the reported literature, the haematite Raman bands are reported with significant shifts in different studies. It is also possible that different kinds of haematite might exist in nature depending on the formation process of the clay. ${ }^{[18]}$ Taking this into account, we think that it is not possible to determine the origin of the haematite (natural or synthesized) based on its Raman spectrum. Therefore, traces of other products such as maghemite, magnetite, and residues of goethite (remaining from thermal treatment) should also be taken into account. However, as these minerals are common in soils and as contamination during burial can never be totally excluded, these interpretations should be considered with caution and here rather posed as suggestions.

Traful lake area: archaeological sites of Alero Larivière, Alero Los Cipreses, and Alero Las Mellizas

Raw pigments found in the three archaeological sites from the Traful lake area (samples 1-8) reveal strong Raman bands at ca. $1300,611,496,412,295,246$, and $225 \mathrm{~cm}^{-1}$, which can be assigned to haematite. ${ }^{[7,11-14,18,19,34,35,37-39]}$

Some samples contain a characteristic band at $147 \mathrm{~cm}^{-1}$, that can be attributed to the $\delta(\mathrm{O}-\mathrm{Ti}-\mathrm{O})$ symmetric bending vibration of $\mathrm{TiO}_{2}$ in the anatase form. The very strong band of anatase occurs in the range of 143 to $154 \mathrm{~cm}^{-1}$ and is pressure dependent. ${ }^{[40-42]}$ In another sample, the band around $153 \mathrm{~cm}^{-1}$ can attributed either to rutile ${ }^{[13]}$ or anatase. In all samples $\alpha$-quartz was identified by bands at 1150, 464, 263, 203, and $128 \mathrm{~cm}^{-1} \cdot{ }^{[12-14]}$ In one sample a double band at 1053 and $1050 \mathrm{~cm}^{-1}$ may indicate the presence of lead carbonate; a band at $1417 \mathrm{~cm}^{-1}$ corresponds to $v_{3} \mathrm{CO}_{3}$ vibration. However, lead was not identified by WDXRF in this sample. Alternatively, from literature, a band at $1048 \mathrm{~cm}^{-1}$ can be associated with $\mathrm{BaCO}_{3}{ }^{[13]}$ but neither $\mathrm{Ba}$ was found by the elemental analysis.

Bands of gypsum $\left(\mathrm{CaSO}_{4} \cdot 2 \mathrm{H}_{2} \mathrm{O}\right)$ were observed at 1007 and $140 \mathrm{~cm}^{-1}$. In the same samples, a band at $362 \mathrm{~cm}^{-1}$ was present, which can be attributed to either $\alpha-\mathrm{Mn}_{2} \mathrm{O}_{3}$ or $\mathrm{Mn}_{3} \mathrm{O}_{4}{ }^{[43]}$ The bands at $1100 \mathrm{~cm}^{-1}$ and $156 \mathrm{~cm}^{-1}$ can be assigned to $v(\mathrm{Si}-\mathrm{O})$ stretch and $v(\mathrm{O}-\mathrm{Al}-\mathrm{O})$ symmetric bending vibrations, respectively, typical for an aluminosilicate structure. ${ }^{[42]}$ The attribution of a band observed at $340 \mathrm{~cm}^{-1}$ is not straightforward. This can either be related to an alluminosilicate phase ${ }^{[42]}$ or to a phase of a manganese oxide. ${ }^{[43]}$ Within the same sample also the identification of a band at $249 \mathrm{~cm}^{-1}$ is unclear, although this might be related to an aluminosilicate form.

In sample 8, apart from the main component, which is haematite, also anhydrite $\left(\mathrm{CaSO}_{4}\right)$ was identified by the bands at 1018 and $415 \mathrm{~cm}^{-1}$, 13] along with carbon black. The Raman bands at 299 and ca. $500 \mathrm{~cm}^{-1}$ (broad) were also observed in other raw pigment samples. They can be attributed to magnetite $\left(\mathrm{Fe}_{3} \mathrm{O}_{4}\right.$, band at $\left.299 \mathrm{~cm}^{-1}\right)_{1}^{[37,44]}$ and to maghemite $\left(\alpha-\mathrm{Fe}_{2} \mathrm{O}_{3}\right.$, band at $\left.500 \mathrm{~cm}^{-1}\right)_{1}^{[14]}$ although a form of manganese oxide $\left(\mathrm{Mn}_{2} \mathrm{O}_{3}\right.$ or $\beta$ $\left.\mathrm{MnO}_{2}\right)^{[8,43]}$ cannot be totally excluded (band at $500 \mathrm{~cm}^{-1}$ ). There is evidence that, when goethite is heated to moderate temperatures $\left(280-350^{\circ} \mathrm{C}\right)$ magnetite is formed. ${ }^{[35,45,46]}$ The presence of maghemite can point out the goethitic origin of haematite. The $\gamma$ $\mathrm{Fe}_{2} \mathrm{O}_{3}$ is formed when heating goethite together with organic matter. ${ }^{[47]}$ Edwards et al. ${ }^{[13]}$ discussed another aspect of the thermal treatment of goethite. Though $\alpha-\mathrm{FeOOH}$ (goethite) can be converted in haematite by heating, $\beta-\mathrm{FeOOH}$ and $\gamma$ - $\mathrm{FeOOH}$ (limonite and lepidocrocite, respectively) are converted to maghemite. The latter is only transformed to haematite by further heating at $600^{\circ} \mathrm{C}$. Furthermore, at temperatures around $250^{\circ} \mathrm{C}$, maghemite could react to magnetite. Although the presence of maghemite or magnetite is often associated with some form of thermal treatment, this magnetite can also be formed from microbiological attack on haematite and its oxy-hydroxyoxides. Moreover, maghemite and magnetite are also associated to natural ochres containing kaolinite. ${ }^{[7,18]}$ However, the finding of anhydrite (opposite to gypsum in other samples) might eventually give a slight indication to support the idea of a thermal treatment of goethite (Fig. 2). 


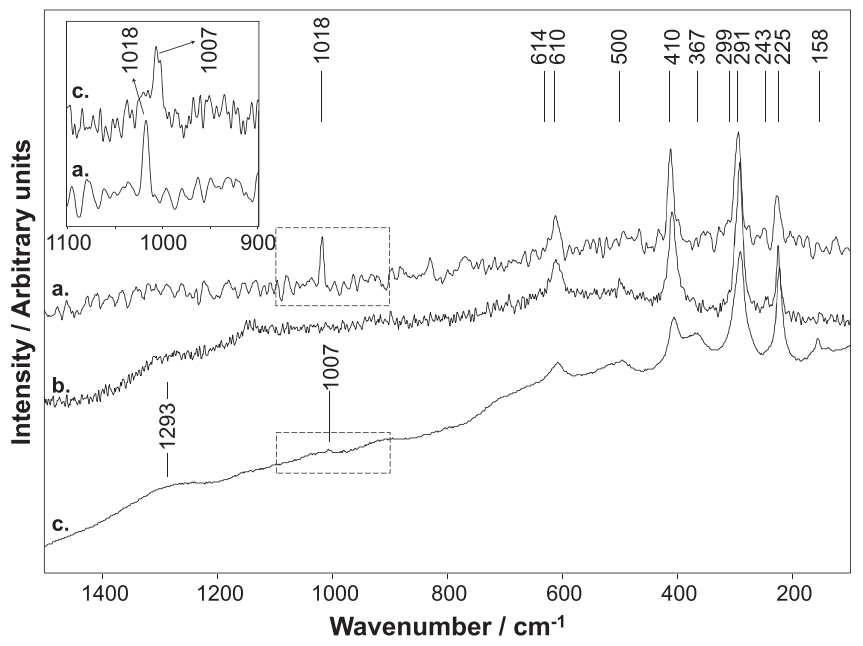

Figure 2. Raman spectra of the Traful area, between 1500 and $100 \mathrm{~cm}^{-1}$.a. and b.: Raw pigments; c.: Rock art. Inset: Raman spectra of samples a and c, between 1100 and $900 \mathrm{~cm}^{-1}$.

Some pigment samples showed the Raman signature of carbon blacks inside their mixtures, but as black designs were not observed on the analysed fragments, the origin of this compound could be attributed to pigment preparation involving organic material, ${ }^{[13,47]}$ organic fossil postdepositional contamination, or human activity.

Two rock art samples were obtained from exfoliated zones in the Traful lake area. As main component in the red mixtures haematite was identified in both samples. Gypsum was found along with different phases of manganese oxides with bands at $515\left(\beta-\mathrm{MnO}_{2}\right)$, $374\left(\mathrm{Mn}_{3} \mathrm{O}_{4}\right)$, and $367\left(\mathrm{Mn}_{3} \mathrm{O}_{4}\right) \mathrm{cm}^{-1}$, ${ }^{[43]}$ anatase with a band at $146 \mathrm{~cm}^{-1},[11-13]$ and $\alpha$-quartz with bands at 465, 215, 206, and $128 \mathrm{~cm}^{-1}$. ${ }^{[12-14]}$ Moreover, carbon black was identified by two broads band at 1589 and $1426 \mathrm{~cm}^{-1} \cdot{ }^{[48]}$ In another measurement performed on the same sample, the two broad bands of carbon black were shifted to lower wavenumbers $\left(1565,1417 \mathrm{~cm}^{-1}\right)$, and a weak double band appeared around $1200 \mathrm{~cm}^{-1}$ (Disordered graphitic lattice ( $A_{1 g}$ symmetry, polyenes, and ionic impurities), thus illustrating the inhomogeneity of the carbon black in the sample. Carbon black either was used on purpose to give a different hue to the paint, but accidental introduction should also be considered (soot from fire, during burial, etc.).

The occurrence of the gypsum may explain the flaking of the rock art. Generally, water dissolves sulphates, and the evaporation on the rock surface generates gypsum crystals. ${ }^{[11,49,50]}$ In one sample manganese oxide $\left(\mathrm{Mn}_{3} \mathrm{O}_{4}\right)$ was identified by its band at $370 \mathrm{~cm}^{-1}$. ${ }^{[43]}$ However, the broad band at ca $500 \mathrm{~cm}^{-1}$ appeared in both samples, which may be attributed to magnetite ${ }^{[44]}$ or maghemite ${ }^{[14]}$ or a phase of manganese oxide $\left(\mathrm{Mn}_{2} \mathrm{O}_{3}\right.$ or $\beta$ $\left.\mathrm{MnO}_{2}\right) \cdot{ }^{[8,43]}$

Micro-Raman analysis of the pottery samples from the Traful Lake area focused on the analysis of red and black spots (Fig. 3). The red colour was associated with haematite, and it is only observed on the surface of the fragments, indicating an oxidizing atmosphere during firing. Anatase was also observed, by the band at $145 \mathrm{~cm}^{-1}$. The analysis of the crystalline form of titanium dioxide can provide useful information about the thermal conditions: as only anatase was found, it suggests that the firing temperature was below $800-950^{\circ} \mathrm{C}$ (below the anatase-rutile phase transition). ${ }^{[14,51]}$ Despite the oxidizing conditions, carbon black (broad bands at 1595 and $1340 \mathrm{~cm}^{-1}$ ) was observed on the samples, which could be the result of partial burning of organic matter

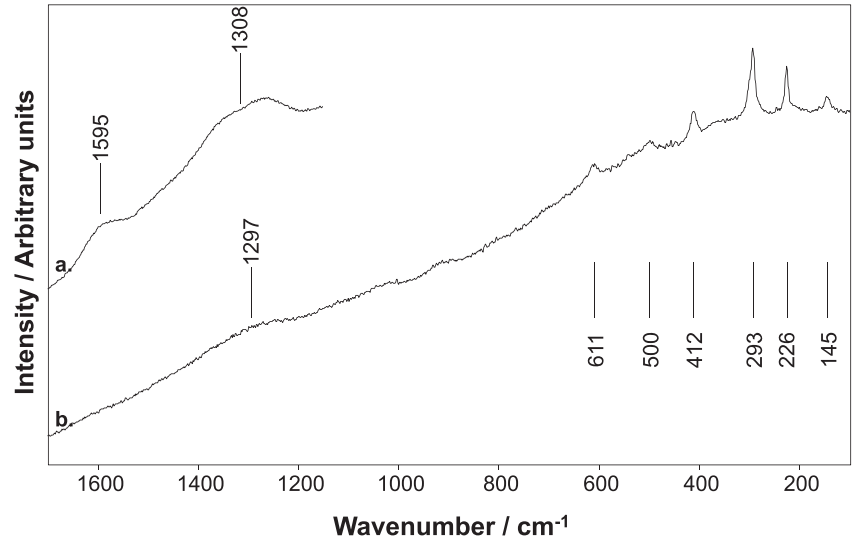

Figure 3. Raman spectra of ceramics samples of the Traful area. a. between 1700 and $1150 \mathrm{~cm}^{-1} ;$ b. between 1700 and $100 \mathrm{~cm}^{-1}$.

in a reducing atmosphere. ${ }^{[52,53]}$ Also the presence of maghemite (band ca. $500 \mathrm{~cm}^{-1}$ ) which rather tends to suggest a reducing atmosphere. From WDXRF analysis, manganese and/or iron were detected in some cases, which could also indicate an inorganic contribution to the black colour. ${ }^{[54]}$

\section{Manso river area: archaeological sites Población Anticura and} ParedónLanfré

In all the raw pigment samples from the Manso river area (samples 14-22) haematite was identified as the main component of the mixtures by the bands at 1300, 609, 497, 406, 290, and $224 \mathrm{~cm}^{-1} \cdot{ }^{[7,11-14,18,19,34,35,37-39]} \alpha$-Quartz (bands at ca. 465, 365, 355, 264, and $\left.201 \mathrm{~cm}^{-1}\right)^{[12-14]}$ and anatase (band at $\left.154 \mathrm{~cm}^{-1}\right)^{[13,14]}$ were also identified inside most of the mixtures.

Two samples reveal the broad Raman bands of carbon black at 1593 and $1310 \mathrm{~cm}^{-1},{ }^{[48]}$ while other samples reveal the Raman spectrum of manganese oxides. Both compounds could be used to darken the hue of the paint, although the presence of carbon could also be explained as a result of the preparation of pigments with organic matter, ${ }^{[13,47]}$ by postdepositional contamination with carbons present in the soil (fossil woods etc.) or by soot from logwood fires. Different phases of manganese oxides were found inside the raw pigments by the characteristic bands at 571 and $566 \mathrm{~cm}^{-1}(\beta$ $\mathrm{MnO}_{2}$ and $\alpha-\mathrm{Mn}_{2} \mathrm{O}_{3}$, respectively), ${ }^{[43]} 577 \mathrm{~cm}^{-1}(\mathrm{MnOOH}){ }_{1}^{[8]}$ $493 \mathrm{~cm}^{-1}$ (bixbyite, $\left.\mathrm{Mn}_{2} \mathrm{O}_{3}\right){ }^{[8]}$ and $368 \mathrm{~cm}^{-1}\left(\mathrm{Mn}_{3} \mathrm{O}_{4}\right){ }^{[43]}$ Bands of feldspars and other aluminosilicate phases could be positively identified from the Raman spectra, revealing a clay-rich pigment mixture (ochre). Bands observed at $450 \mathrm{~cm}^{-1}$ might point to a Cabearing plagioclase feldspar, ${ }^{[10]}$ whereas a double band at 144 and $128 \mathrm{~cm}^{-1}$, which was observed in several samples, might be indicative for an alluminosilicate phase ${ }^{[42,55,56]}$ (Fig. 4). In the samples from this archaeological area, no gypsum or anhydrite was observed. However, in one sample a double band at 1470 and $1466 \mathrm{~cm}^{-1}$ was observed, which can be assigned to the presence of whewellite. ${ }^{[11,13,19]}$

Similar to the Traful samples, in some of these Manso samples, the band at ca. $500 \mathrm{~cm}^{-1}$ (attributed to maghemite ${ }^{[14]}$ ) or a manganese oxide ${ }^{[8,43]}$ was observed. As pointed out before, the presence of maghemite may point towards a goethite to haematite transition, ${ }^{[13,47]}$ eventually because of thermal treatment of the clay. Moreover, in some samples along with the band at ca. $500 \mathrm{~cm}^{-1}$, a 


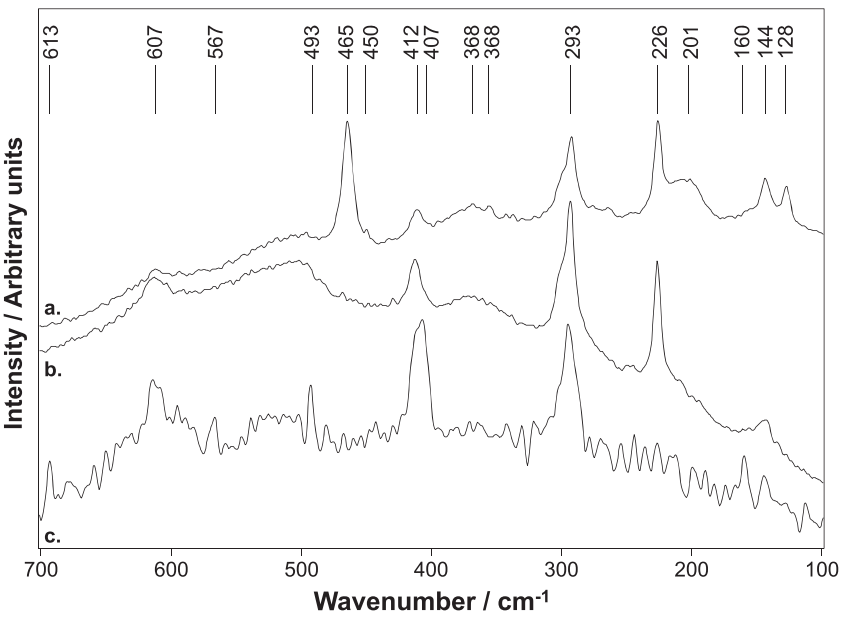

Figure 4. Raman spectrum of a raw pigment sample from the Manso area, between 1500 and $100 \mathrm{~cm}^{-1}$.

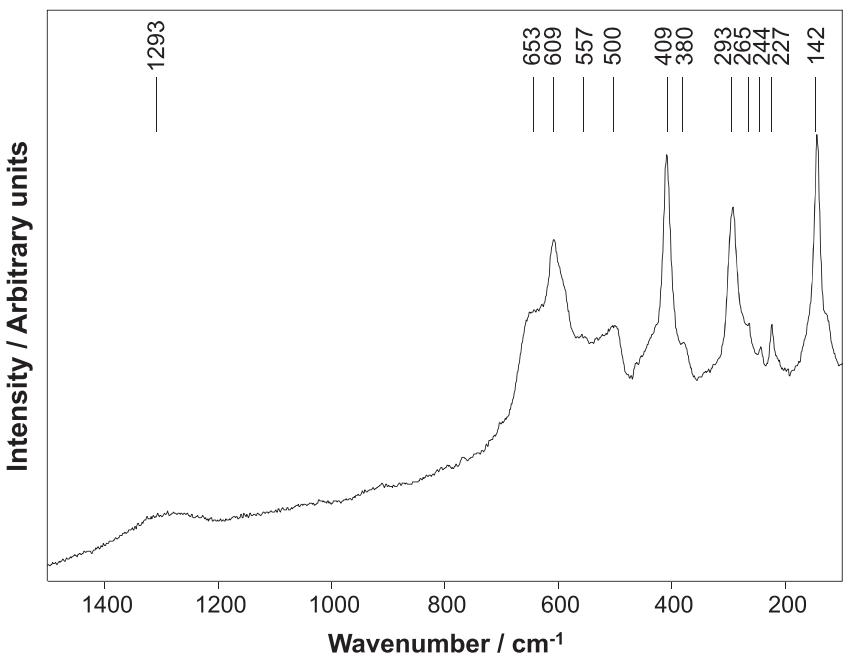

Figure 5. Raman spectra of a raw pigment samples from the Manso area, between 700 and $100 \mathrm{~cm}^{-1}$, showing the presence of different compounds.

band at $653 \mathrm{~cm}^{-1}$ is observed, which might be attributed to a low degree of crystallinity in disordered haematite (Fig. 5). Also bands at 380 and $265 \mathrm{~cm}^{-1}$, attributed to lepidocrocite $(\gamma-\mathrm{FeOOH})^{[38]}$ were present. These observations tend to support the hypothesis that the red pigment was produced by heating iron-containing clay material. However, it should be remarked that the assignment of the $653 \mathrm{~cm}^{-1}$ band to disordered haematite can be argued. When studying band positions of iron oxides between 670 and $650 \mathrm{~cm}^{-1}$, different band assignments were found in literature (Table 2). Moreover, disordered haematite can be formed not only by heating goethite to haematite, but also through different processes such as grinding, biodegradation, and weathering. ${ }^{[35]} \mathrm{How}-$ ever, the retrieval of traces of lepidocrocite and maghemite and the disordered structure of haematite may imply the use of a heated clay or the use of goethite for obtaining haematite. ${ }^{[13,47]}$

In the oldest sample (dating 8000 year BP) of raw pigment material, highly crystalline haematite and anatase were identified, whereas in a more recent sample of the same site (700 year BP) the haematite bands were broader and $\beta-\mathrm{MnO}_{2}$, maghemite, $\alpha$ quartz, and alluminosilicates were present. The presence of the traces of other phases in the more recent sample, along with the
Table 2. Overview of Raman band positions as found in literature on rock art and on iron oxides in the spectral range between 670 and $650 \mathrm{~cm}^{-1}$

\begin{tabular}{|c|c|c|}
\hline $\begin{array}{l}\text { Reported Raman } \\
\text { band position } \\
\left(\mathrm{cm}^{-1}\right)\end{array}$ & Assignment & Reference \\
\hline 663 & Wustite $(\mathrm{FeO})$ or magnetite $\left(\mathrm{Fe}_{3} \mathrm{O}_{4}\right)$ & 38 \\
\hline ca. 660 & Disordered or doped haematite & $7,12,14,18,37$ \\
\hline 658 & $\begin{array}{l}\text { Al-O-Si vibration in kaolinite-rich } \\
\text { clays }\end{array}$ & 34,42 \\
\hline 657 & $\begin{array}{l}\text { Disordered haematite, produced by } \\
\text { heating goethite }\end{array}$ & 35 \\
\hline 655 & Magnetite $\left(\mathrm{Fe}_{3} \mathrm{O}_{4}\right)$ & 6 \\
\hline 655 & $\begin{array}{l}\text { Magnetite or maghemite, associated } \\
\text { with haematite in ochre }\end{array}$ & 57 \\
\hline
\end{tabular}

band broadening, tends to suggest that this paint sample was produced by heating of iron-containing clays (Fig. 6).

Three pigment samples were scraped from grinding tools from the Manso river area. In all the cases micro-Raman analysis detected haematite (bands at 612, 495, 411, 292, 245, and $\left.225 \mathrm{~cm}^{-1}\right),{ }^{[7,11-14,18,19,34,35,37-39]}$ although WDXRF failed to identify Fe in all but one of the samples.

Micro-Raman analysis of the red spots on four shell fragments and one bead from the Manso area were also performed (Fig. 7). These samples showed the presence of calcium carbonate (1085, 705,273 , and $\left.153 \mathrm{~cm}^{-1}\right)$. Bands at ca. 207, 180, and $142 \mathrm{~cm}^{-1}$ could be attributed to $\alpha$-quartz ${ }^{[7,12-14]}$ and anatase. ${ }^{[12,13]}$ On the red spots of the shell fragments and the bead, haematite was identified (1310, 609, 494, 408, 291, 242, and $\left.\left.225 \mathrm{~cm}^{-1}\right)\right)^{[7,11-14,18,19,34,35,37-39]}$ The detection of haematite in the shell fragments suggests that these had been used as containers to prepare red paint. ${ }^{[58]}$

In two samples, carbon black was observed by its two characteristic broad bands at ca. 1587 and $1332 \mathrm{~cm}^{-1} \cdot{ }^{[48]}$ WDXRF detected, besides $\mathrm{Ca}$ and $\mathrm{Fe}$, also traces of $\mathrm{Sr}, \mathrm{K}, \mathrm{P}$, and $\mathrm{Si}$ which could be associated to shell components.

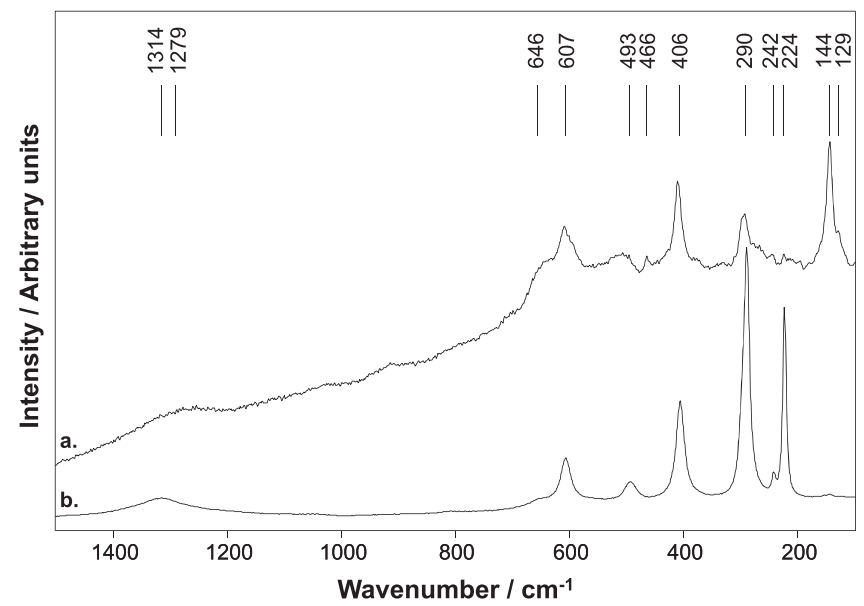

Figure 6. Raman spectrum of two samples from the Manso area, between 1500 and $100 \mathrm{~cm}^{-1}$. a. Spectrum of a sample dating 700 B.P.; b. Spectrum of a sample dating 8000 B.P. 


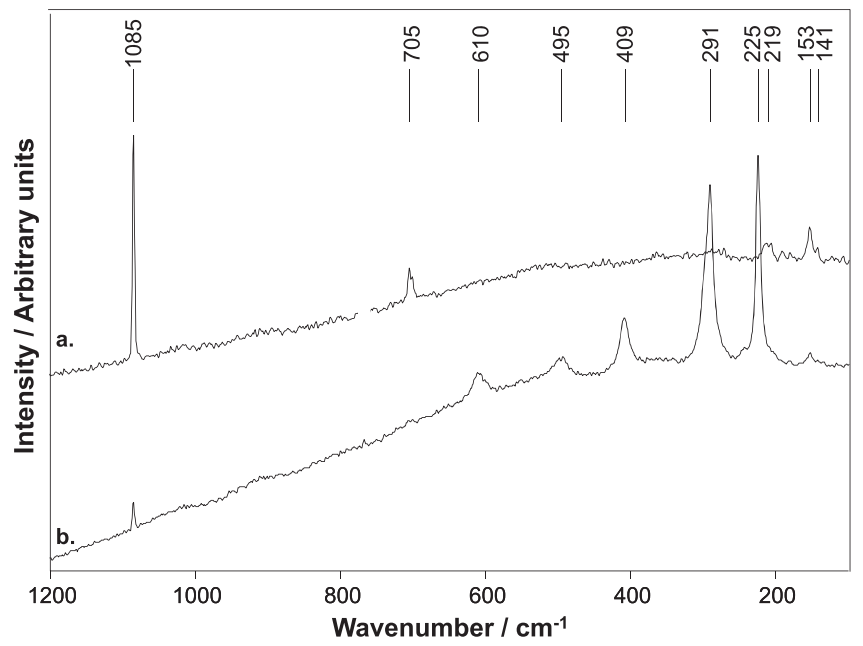

Figure 7. Raman spectrum of a shell samples from the Manso area, between 1200 and $100 \mathrm{~cm}^{-1}$. Spectrum a. shows mainly the bands of calcium carbonate, while in spectrum $b$ the bands of haematite are observed.

\section{Conclusion}

The results presented in this paper indicate that micro-Raman spectroscopy is an interesting approach to study archaeological materials in a non-destructive way. Thirty samples from huntergatherer sites in Northern Patagonia were examined. These samples consist of raw pigment samples, fragments of rock art, grinding tools, shells, beads, and ceramics. It is found that haematite is the predominant chromophore in the samples, sometimes associated with manganese oxides or carbon black, or black iron oxides, resulting in a darker hue. On the other hand, in some cases anatase or gypsum was identified, which tend to lighten the observed colour. The presence of associated silicates in the samples indicates that ochres (earth pigments) were used, as opposed to pure haematite. The presence of other iron oxides, like magnetite, maghemite, and lepidocrocite, tends to indicate that heat might be applied on some samples, to transform the clay source material to the haematite-containing pigment, although other explanations for the presence of these minerals cannot be totally excluded.

\section{Acknowledgements}

Sylvia Lycke is greatly acknowledged for her help during the microRaman analysis of the samples and Ana Forlano who helped us with the design of Fig. 1. This project was made possible by the Bilateral Cooperation Programme between Research Foundation Flanders (FWO Vlaanderen) and Ministerio de Ciencia, Tecnología e Innovación Productiva (MINCyT) FW 12/08-Grant VS.030.13N. The authors thank Ghent University for its financial support through the concerted research actions (GOA) programme.

\section{References}

[1] M. T. Boschin, M. S. Maier, G. I. Massaferro, Anthropologie 2011 115, 360.

[2] M. S. Maier, D. L. A. de Faria, M. T. Boschín, S. D. Parera, M. F. del Castillo Bernal, Vib Spectrosc 2007 44, 182.

[3] L. Darchuk, Z. Tsybrii, A. Worobiec, C. Vazquez, O. M. Palacios, E. A. Stefaniak, G. G. Rotondo, F. Sizov, R. Van Grieken, Spectrochim. Acta A 2010, 75, 1398.

[4] C. Vazquez, O. M. Palacios, L. Darchuk, L. M. M. Parra, Powder diffraction 2010, 25, 264.
[5] D. C. Smith, M. Bouchard, M. Lorblanchet, J. Raman Spectrosc. 1999, 30, 347.

[6] H. Gomes, P. Rosina, H. Parviz, T. Solomon, C. Vaccaro, J. Archaeol. Sci. 2013, 40, 4073.

[7] C. Lofrumento, M. Ricci, L. Bachechi, D. De Feo, E. M. Castellucci, J. Raman Spectrosc 2012, 43, 809.

[8] A. Zoppi, G. F. Signorini, F. Lucarelli, L. Bachechi, J. Cult. Herit. 2002, 3, 299.

[9] S. Gialanella, R. Belli, G. Dalmeri, I. Lonardelli, M. Mattarelli, M. Montagna, L. Toniutti, Archaeometry 2011, 53, 950.

[10] H. Gomes, H. Collado, A. Martins, G. H. Nash, P. Rosina, C. Vaccaro, L. Volpe, Mediter. Archaeol. Archaeometry 2015, 15/1, xx.

[11] A. Hernanz, J. F. Ruiz-Lopez, J. M. Gavira-Vallejo, S. Martin, E. Gavrilenko, J. Raman Spectrosc. 2010, 41, 1394.

[12] A. Hernanz, J. M. Gavira-Vallejo, J. F. Ruiz-Lopez, S. Martin, A. Maroto-Valiente, R. de Balbin-Behrmann, M. Menendez, J. J. Alcolea-Gonzalez, J. Raman Spectrosc 2012, 43, 1644.

[13] H. G. M. Edwards, E. M. Newton, J. Russ, J. Mol. Struct. 2000, 550-551, 245.

[14] M. Olivares, M. C. Zuluaga, L. A. Ortega, X. Murelaga, A. Alonso-Olazabal, M. Urteaga, L. Amundaray, I. Alonso-Martin, N. Etxebarria, J. Raman Spectrosc. 2010, 41, 1543

[15] S. Lahlil, M. Lebon, L. Beck H. Rousselière, C. Vignaud, I. Reiche, M. Menu, P. Paillet, F. Plassard, J. Raman Spectrosc. 2012, 43, 1637.

[16] A. Tournié, L. C. Prinsloo, C. Paris, P. h. Colomban, B. Smith, J. Raman Spectrosc. 2011, 42, 399.

[17] A. Bonneau, D. G. Pearce, A. M. Pollard, J. Archaeol. Sci. 2012, 39, 287.

[18] L. Prinsloo, W. Barnard, I. Meiklejohn, K. Hall, J. Raman Spectrosc 2008, $39,646$.

[19] L. Prinsloo, A. Tournié, P h. Colomban, C. Paris, S. T. Bassett, J. Archaeol. Sci. 2013, 40, 2981.

[20] J. J. Armesto, P. L. Lobos, M. K. Arroyo, in Ecología de los Bosques Nativos de Chile, (Eds: J. J. Armesto, C. Villagran, M. K. Arroyo), Editorial Universitaria, Santiago de Chile, 1995, pp. 23-28.

[21] A. Cabrera, A. Willink, Biogeografía de América Latina, Monografía № 13, OEA. 1980.

[22] F. X. Pereyra, C. Bellelli, M. M. Podesta, in: Il Congresso do quaternario de paises de linguas Ibericas, 12-19 August 2003, Recife/PE (Brasil).

[23] M. F. Gargiulo, Rev. Asoc. Geol. Argent 2006, 61, 218.

[24] B. González, Geología del área entre San Carlos de Bariloche y LLao LLao. Fundacion Bariloche 1973, 16, 1.

[25] A. Ferrer, F. Pereyra, D. Villegas, Raga 1999, 54/3, 270.

[26] C. J. Gradin, Segundas Jornadas de Investigadores en Arqueología y Etnohistoria del Centro Oeste del País, (Ed: M. Tamagnini), Universidad Nacional de Río Cuarto, Río Cuarto, 1999, p. 85.

[27] A. M. Albornoz, E. M. Cúneo, Arte en las Rocas. Arte Rupestre, Menhires y Piedras de Colores en Argentina, (Eds: M. Podestá, M. de Hoyos), Sociedad Argentina de Antropología and Asociación Amigos del INAPL, Buenos Aires, 2000, p. 163.

[28] M. J. Silveira, L. López, V. Aldazabal, Anuario de Arqueología 2013, 5, 85.

[29] M. J. Silveira, L. López, V. Aldazabal. Comechingonia virtual 2014, VIII, 2.

[30] V. Aldazabal, A. Micaelli, RUNA 2007, 27, 85.

[31] V. Aldazabal, M. Silveira, G. Custo, M. Ortiz, Bol. Museo Chil. de Arte Precol. 2014, 19, 2.

[32] C. Bellelli, M. Carballido Calatayud, P. M. Fernández, Resúmenes XVIII Cong. Nac. Arq. Arg. 2013, 516.

[33] P. M. Fernández, M. Carballido Calatayud, C. Bellelli, M. Podestá. Tendencias Teórico-Metodológicas y Casos de Estudio en la Arqueología de la Patagonia, (Eds: A. F. Zangrando, R. Barberena, A. Gil, G. Neme, M. Giardina, L. Luna, C. Otaola, S. Paulides, L. Salgán, A. Tivoli), Museo de Historia Natural de San Rafael, Sociedad Argentina de Antropología e Instituto Nacional de Antropología y Pensamiento Latinoamericano, San Rafael, 2013, p. 167.

[34] D. Bikiaris, S. Daniilia, S. Sotiropoulou, O. Katsimbiri, E. Pavlidou, A. P. Moutsatsou, Y. Chryssoulakis, Spectrochim. Acta A 1999, 56, 3.

[35] D. L. A. de Faria, F. N. Lopes, Vib. Spectrosc. 2007, 45, 117.

[36] F. Froment, A. Tournie, P. h. Colomban, J. Raman Spectr. 2008, 39, 560.

[37] D. A. de Faria, S. V. Silva, M. T. de Oliveira, J. Raman Spectr. 1997, $28,873$.

[38] R. J. Thibeau, C. W. Brown, R. H. Heidersbach, Appl. Spectrosc. 1978, 32, 532.

[39] S. Das, M. J. Hendry, Chem. Geol. 2011, 290, 101.

[40] U. Balachandran, N. G. Eror, J. Sol. St. Chem. 1982, 142,276-282.

[41] T. Ohsaka, F. Izumu, Y. Fujiki, J. Raman Spec. 1978, 7, 321.

[42] R. L. Frost, Clays Clay Min. 1995, 43, 191. 
[43] F. Buciuman, F. Patcas, R. Craciun, D. R. T. Zahn, Phys. Chem. Chem.Phys. 1999, 1, 185.

[44] T. R. Hart, S. B. Adams, H. Tempkin, in Proceedings of the $3^{\text {rd }}$ International Conference on Light Scattering in Solids (1976), edited by M. Balkanski, R. Leite, S. Porto, p.254, Flamarion, Paris.

[45] M. J. Dekker, Geophys. J. Int. 1990, 103, 233.

[46] Ö. Özdemir, D. J. Dunlop, Earth Planet. Sci. Lett. 2000, 177, 59.

[47] M. P. Pomiès, M. Menu, C. Vignaud, Archaeometry 1999, 41, 275.

[48] A. Coccato, J. Jehlicka, L. Moens, P. Vandenabeele, J. Raman Spectrosc 2015, current issue (Submitted for publication).

[49] A. Hernanz, M. Mas, B. Gavilan, B. Hernandez, J. Raman Spectrosc. 2006, $37,492$.

[50] A. Hernanz, J. M. Gavira-Vallejo, J. F. Ruiz-Lopez, J. Optoelectron. Adv. Mat. 2007, 9, 512.
[51] F. C. Gennari, D. M. Pasquevich, J. Am. Ceram. Soc. 1999, 82, 1915.

[52] J. M. Pérez, R. Esteve-Tébar, Archaeometry 2004, 46, 607.

[53] J. Striova, C. Lofrumento, A. Zoppi, \E. M. Castellucci, J. Raman Spectrosc. 2006, 37, 1139

[54] C. Vázquez, M. Maier, S. D. Parera, H. Yacobaccio, P. Solá, Anal. Bioanal. Chem. 2008, 391, 1381.

[55] A. Wiewiora, T. Wieckowski, A. Sokolowska, Arch. Mineral. 1979, 135, 5.

[56] C. T. Johnston, G. Sposito, R. R. Birge, Clays \& Clay Miner. 1985, 33, 483.

[57] F. Ospitali, D. C. Smith, M. Lorblanchet, J. Raman, Spectrosc. 2006, 37, 1063.

[58] O. M. Palacios, M. S. Maier, C. Vázquez. Characterization of a red paste in an archaeological shell by FTIR, GCMS and $\mathrm{X}$ ray techniques. Proceedings of the IRUG9 Conference, 23-25. March 2010. Facultad de Ciencias Exactas. UBA. Buenos Aires. 